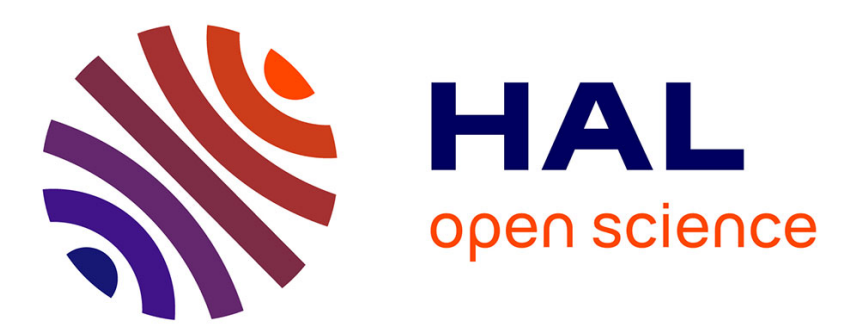

\title{
Systemic Impact Evaluation: A Methodology for Complex Agricultural Development Projects. The Case of a Contract Farming Project in Guinea
}

\author{
Jocelyne Delarue, Hubert Cochet
}

\section{- To cite this version:}

Jocelyne Delarue, Hubert Cochet. Systemic Impact Evaluation: A Methodology for Complex Agricultural Development Projects. The Case of a Contract Farming Project in Guinea. The European Journal of Development Research, 2013, 25 (5), p.778-796. 10.1057/ejdr.2013.15 . halshs-01374496

\author{
HAL Id: halshs-01374496 \\ https://shs.hal.science/halshs-01374496
}

Submitted on 7 May 2020

HAL is a multi-disciplinary open access archive for the deposit and dissemination of scientific research documents, whether they are published or not. The documents may come from teaching and research institutions in France or abroad, or from public or private research centers.
L'archive ouverte pluridisciplinaire HAL, est destinée au dépôt et à la diffusion de documents scientifiques de niveau recherche, publiés ou non, émanant des établissements d'enseignement et de recherche français ou étrangers, des laboratoires publics ou privés. 


\title{
Original Article
}

\section{Systemic Impact Evaluation: A Methodology for Complex Agricultural Development Projects. The Case of a Contract Farming Project in Guinea}

\author{
Jocelyne Delarue $^{\mathrm{a}}$ and Hubert Cochet $^{\mathrm{b}}$ \\ ${ }^{a}$ Agence Française de Développement, Evaluation and Capitalization Unit, Paris, France. \\ E-mail: jocelyne.delarue@gevalor.org \\ ${ }^{\mathrm{b}}$ Agro Paris Tech, Comparative Agriculture and Agricultural Development Research Unit, Paris, France. \\ E-mail: hubert.cochet@agroparistech.fr
}

\begin{abstract}
This article presents a mixed-method approach used to analyse the impact of a complex agricultural development project, the SOGUIPAH (Guinean Oil Palms and Rubber Company) project designed to promote oil palm and rubber cultivation in Guinea. At farm level, the combination of a farming system analysis and an economic analysis with a counterfactual scenario enables us to quantify impact on the farmers' income and to account for related impact heterogeneity. These comparisons reveal a somewhat limited impact of the project as a whole, though with a considerable heterogeneity across the types of farm households it reaches.

Cet article présente une méthode originale d'analyse d'impact d'un projet de développement agricole complexe, le projet SOGUIPAH (projet de palmier à huile et hévéa) en Guinée forestière. En faisant appel conjointement à l'analyse systémique à l'échelle des unités de production (systèmes de production) et à l'évaluation économique incluant un scénario contrefactuel, la démarche proposée permet de quantifier l'impact du projet sur le revenu des agriculteurs et de mettre en évidence le caractère hétérogène de cet impact. Cette comparaison révèle un impact des plus limités à l'échelle globale et de très forts contrastes selon les catégories de producteurs.
\end{abstract}

European Journal of Development Research (2013) 25,778-796. doi:10.1057/ejdr.2013.15; published online 2 May 2013

Keywords: impact evaluation; systemic analysis; agricultural assessments; agro-industrial projects; Guinea; contract farming

\section{Introduction}

Agricultural development projects usually combine multiple inputs and activities in order to raise farmers' production, productivity and income. Such interventions are complex and often evolve during implementation, which often lasts for several years. Moreover, this type of project is part of a complex environment where economic, social and environmental conditions are constantly changing. In addition, the potential beneficiaries themselves face diverse initial conditions in terms of access to production factors, knowledge and strategies.

A simple comparison of treatment and control groups, using experimental or quasiexperimental methods, allows the short-term average treatment effect of such projects to be evaluated. Although these methods would also be appropriate for measuring the impact of the innovations proposed by a project before they are scaled up, they are less suited to assessing complex impacts of such projects in terms of mid- or long-term effects and impact heterogeneity.

A high degree of project complexity argues in favour of using qualitative approaches to analyse and give a fuller understanding of its effects. Amongst the possible methods, agrarian 
system analysis and farming system analysis (Mazoyer and Roudart, 2005; Cochet and Devienne, 2006; Cochet, 2012) are often used ex ante or ex post to assess the benefits of agricultural projects for different types of farmers. The use of financial analysis at farm level is also frequently used to model the evolution of economic indicators associated with the project's intervention (for example, Gittinger, 1972). Yet to our knowledge, these systemic and economic methods are never combined with a sound counterfactual approach to obtain an in-depth evaluation of the impact of these projects.

This article shows that a rigorous and information-rich qualitative analysis within a treatment/ control setting constitutes a valuable alternative to a purely quantitative approach to impact evaluation for this type of project. Furthermore, we argue that a systemic approach, as described below, can usefully improve the internal validity of an impact evaluation based on qualitative analysis, when combined with the purposeful sampling of households from comparable communities in order to construct a comparison group.

We thus developed and tested the systemic impact evaluation method on an agricultural project in Guinea, called Guinean Oil Palms and Rubber Company (SOGUIPAH) project. This project is typical of highly complex interventions that combine several innovations, notably the introduction of oil palm and rubber plantations and lowland development. In addition, the project requisitioned land to develop industrial plantations, which had a direct impact on a number of households and on land availability in general. The indirect effects of SOGUIPAH's intervention were observable in local palm oil prices and the local labour market.

In the present case, the fact that the impact evaluation was undertaken in 2005, 15 years after the project started, without baseline data or regular data collection, posed some methodological challenges.

This article presents the systemic impact evaluation method and explains step by step the multi-level analysis it implies.

As a first step, an agrarian system analysis was carried out so as to understand the contextual variables that might have affected impacts. The environmental, social, economic and institutional setting of the project was studied.

This agrarian system analysis helped to elucidate various local development trends, which thus made it possible to produce a typology of the different types of farms (also termed 'farming systems') that existed before project start-up. This compensated for the absence of baseline data and enabled a purposeful sampling method to be used to undertake case studies of farms for each baseline farming system in the three villages surveyed.

Our farming system analysis completed this typology by furnishing a detailed description of the situation of each farm-case before project start-up, and their structural evolutions with or without SOGUIPAH. This step was based on in-depth interviews ${ }^{1}$ that collected recall information on the changes in land ownership or renting status, land use and the adoption of technical innovations. Systematic on-the-spot cross-checking of this information by the researcher allowed the farmers' strategies to be clarified and possible recall errors to be detected when there was a mismatch between strategies and information. These case studies enabled us to propose models of how the farming systems had evolved over time.

In addition, the financial analysis of each farming system, with and without SOGUIPAH, relied on the models elaborated and on a cropping system analysis. Agronomic and economic data collected at this final level of analysis were necessary to complete the model for evaluating SOGUIPAH's impact on the farms' income. The triangulation of data on yields and productivity from different sources, field observations and measurements permitted us to further control for the validity of some recall-based data. Finally, information on the evolution of relative prices 
(of crops or land) was used to corroborate strategic changes in the farming systems and to calculate the typical farms' incomes.

The result of this ex post analysis is the quantification of SOGUIPAH's impact on the farmers' income, from project start-up until 2005. It can also serve as the basis for an ex ante assessment of how the impacts will most likely materialize in the long run, thus providing a sound assessment of the total impact of the project throughout the lifetime of its outputs (the plantations and developed lowlands).

The economic impact models show that the limited areas of plantations that were distributed by SOGUIPAH to most of the project beneficiary families make no difference compared with the situation of the 'without project' group, for whom other opportunities arose. There is, nevertheless, considerable impact heterogeneity across the types of farm households. The greatest impact is to be found on farming systems that initially had small plots of land, as these farmers joined the project at a very early stage and were able to use their new income to buy more land and create further plantations. On the other hand, many large landowners joined the project much later, and thus only obtained support for a small plantation. The most interesting effect of the project is the emergence of spontaneous plantations by non-beneficiaries, resulting in positive indirect impacts. Beyond impact quantification, an in-depth analysis of the impact pathways teaches us that there are real opportunities for improving the project's direct and indirect impacts, notably through a better supply of planting material.

The article is organized as follows. The first section 'The Guinean Oil Palms and Rubber Company (SOGUIPAH)' presents SOGUIPAH and the project theory. The next section 'A Mixed-Method Approach' presents the combination of methods used and a step-by-step overview of systemic impact evaluation. The subsequent section 'Results' presents results in terms of the changes in agrarian and farming systems attributable to the project, and in terms of the economic impacts on the farmers' incomes. The conclusions are presented in the final section 'Conclusion'.

\section{The Guinean Oil Palms and Rubber Company (SOGUIPAH)}

The Guinean Oil Palms and Rubber Company (SOGUIPAH) was founded in 1987 by the Guinean government with the mandate to develop palm oil and rubber production at the national level. SOGUIPAH's first agro-industrial unit, and the only one to date, was implemented in the districts of Diecke and Bignamou (in the Yomou prefecture), in the extreme South of Guinea. This location was chosen for its agro-ecological conditions, which are favourable to palm tree plantations: high rainfall $(1800-2000 \mathrm{~mm})$ well distributed throughout the year, moderately sloped land and good soil quality.

The objectives of SOGUIPAH project were threefold:

- Produce rubber for export

- Produce palm oil for the national market

- Ensure social and economic development in its intervention zone

With the support of several donors, SOGUIPAH quickly set up a programme of industrial plantations, owned by SOGUIPAH and worked by salaried employees. With the objective of planting 7000 ha of rubber trees and 3000 ha of oil palms, the SOGUIPAH negotiated the requisition of 22830 ha with villagers against indemnities. Between 1988 and 1993, 4574 ha were planted with rubber trees and 1558 ha with oil palms, the remaining area being requisitioned for use at a later date. 
In addition, a contract farming scheme supported by several donors was implemented between 1989 and 2002 to establish plantations and develop lowland for irrigated rice production. This was at the farmers' request and on their own land. The objectives were to plant 1000 ha with rubber trees and 2000 ha with oil palms.

The priority for the plantations was given to those farmers who agreed to produce irrigated rice for self-consumption, the objective being to encourage them to abandon the slash-and-burn practices said to be responsible for environmental degradation. Accordingly, the plots no longer used for rain-fed rice production were to be planted with oil palms and rubber trees. The assumption adopted by SOGUIPAH was that a family exploiting 0.5 ha of developed lowland, 1 ha of palm trees and 2 ha of rubber trees would earn 10 times more than before the project. The contract drawn up between SOGUIPAH and the farmer binds the latter to sell all his production to SOGUIPAH and to reimburse the cost of the plantation. This contract farming scheme resulted in the planting of 1866 ha of oil palm and 1760 ha of rubber trees and in the improvement of 1298 ha of lowland areas for irrigated rice production. The number of individuals directly concerned by the project numbered 4209 in 2002.

Project activities that involved the village households can be grouped into five main strands. First, the project is responsible for developing the plantations. This includes producing the planting material (hybrid oil palms of the tenera variety and grafted rubber plants from a variety of clones), organizing upstream the supply of inputs and providing the farmers with technical support. Second, SOGUIPAH provides training and advice for adequate maintenance and exploitation of the plantations. Third, the project develops the lowland and also provides training, improved rice varieties and fertilizer for the first 3 years. Fourth, the project buys rubber and palm bunches, which it then processes in its processing unit. Finally, SOGUIPAH opens or maintains feeder roads for the collection of harvests.

Moreover, SOGUIPAH employs many villagers as tappers for its own rubber plantations or as workers in its factory, and has appointed a few locals to middle-management positions.

The choice of plots to be planted by the villagers was approved by SOGUIPAH on the basis of two criteria: clear land ownership and favourable conditions for plant growth. However, a third criterion gradually emerged as a key consideration: accessibility. Although SOGUIPAH had opened new feeder roads in the early stages of the project, priority was later given to the plots bordering existing roads.

In contractual plantations, the farmer was required to prepare the plot at his own expense. He then obtained a loan for planting material and inputs, and received monetary compensation from SOGUIPAH for the labour involved in plantation maintenance. The loan amount for 1 ha plantation was estimated in the last feasibility study at $€ 1863$ for rubber and $€ 2823$ oil palm. The amount to be reimbursed (capital plus interest) was converted by SOGUIPAH into a quantity of products to be delivered for free, representing 3.257 tons of dry rubber and 72.6 tons of palm bunches. This implies the withdrawal of 20 per cent and 15 per cent from each delivery of rubber and palm bunches, respectively, until the loan amount is repaid.

For the lowland development, the owner was required to abandon his land, which was then redistributed among several farmers, including the owner. The works were undertaken by SOGUIPAH, and the plots were allocated to the farmers on credit. In the last feasibility study, the cost of developing 1 ha was estimated at $€ 2607$. At first, the amount to be reimbursed, which partly covered the total cost of irrigation work, was converted into a quantity of paddy rice (4 tons per hectare). Given that it was difficult to obtain and collect the rice from the farmers, SOGUIPAH eventually decided to fix the amount owed to under $€ 150$.

To analyse the treatment situation, two Kpèle villages were chosen among the 16 villages concerned by the SOGUIPAH project. The project's intervention zone is relatively homogeneous 
in terms of geographic characteristics: the choice of these two villages is thus justified to illustrate variability of the project's impacts. The village of Kpoo was selected so as to examine the effects of requisitioning part of the village land for industrial plantations (62 per cent of the village's territory was seized). The dynamics of the contractual plantations and the impact of lowland improvements were also studied. The village of Guilamou was chosen to observe a second type of project situation: that of a more isolated village whose lands had not been requisitioned for industrial plantations, but whose farmers did participate in the contract farming scheme. We will discuss below the selection of the village that was identified as being suitable as a counterfactual.

The expected impacts from the above-described intervention are clearly multidimensional. The SOGUIPAH project has modified land distribution at household and village levels and created job opportunities. The project has had an impact on cropping strategies at farm level, which will in turn have effects on time-use and workload peaks. Land and labour productivity are expected to increase thanks to the project, but, ultimately, the adoption of plantations and irrigated rice cultivation may cause the farmers to abandon other activities. This may mean that the project did not generate any clear economic net benefit for the farmer. In what follows, we will therefore focus our attention on studying the impact of SOGUIPAH on farmers' income, as a key indicator integrating all changes at household level. Moreover, as contended above, understanding the impact heterogeneity with respect to the pre-existing differences between the farmers is crucial to evaluating the project's contribution to local development, hence our focus on income evolution for different farming systems.

The evaluation of the impacts of SOGUIPAH on the farmers could, in fact, have been the first step of a cost-benefit analysis of the project as a whole. However, in order to ensure full collaboration with the project stakeholders, the research was intentionally directed away from this goal.

\section{A Mixed-Method Approach}

The impact evaluation of SOGUIPAH combines three different methods: a counterfactual approach, a qualitative systemic approach and an economic modelling approach.

Before presenting the methods used in more detail, it is necessary to point out the challenges facing this evaluation. First, the impact evaluation could not rely on previously collected data. There was little information on the baseline situation (except for Merusi, 1989), and there had been no monitoring of the farmers' incomes. It was therefore necessary to use a recall method and data triangulation, with all the required precautions to ensure a rigorous reconstruction of the baseline and of past evolutions. Second, since the impact evaluation was carried out in 2005, it is in fact an in itineri more than ex post evaluation, as the plantations were only a few years old at the time. It was essential to propose a model of the future evolution of the 'with-project' and 'without-project' groups in order to assess the impact on the lifetime of the plantations. Lastly, this type of project is extremely complex, which means that it is necessary to take into account the processes and the diversity of the farmers' initial situations.

For all these reasons, a qualitative rather than quantitative approach was preferred in order to ensure a high quality of data, capture the complexity of the project and gain a better understanding of the trend of the sector's dynamics and farming strategies for ex-ante assessment. A counterfactual approach was also essential, as we consider that it is inseparable from a rigorous impact evaluation. It is the novel combination of these two approaches that constitutes the strength of the systemic impact evaluation method. 
The counterfactual approach supposes that we can observe comparable units (villages and farms in this case) that have evolved with and without the project (Gertler et al, 2011). In this case, we employ a two-step matching method. First, two villages involved in the SOGUIPAH's project (treatment villages) are matched with a comparison village outside SOGUIPAH's intervention zone. Second, we match participant and non-participant households within the treatment villages to non-participant households in the comparison village.

The hypothesis of the comparability of the different observation units before the project, which are not supported by baseline data, is the greatest potential source of bias in this impact evaluation. Participants differ from non-participants in a number of community- and householdlevel observable characteristics that may have a direct effect on income. As a result, part of the observed difference between participants and non-participants may reflect initial differences rather than the impact of SOGUIPAH. This difficulty was overcome by using the systemic approach: the agrarian system and the farming system concepts provide the basis for the two-step matching process.

The concept of 'agrarian system' helps to deepen the understanding of the situation, functioning and conditions of a society's agricultural sector at a given moment in time. It involves exploring both the operating and reproductive modes of an ecosystem, the social relationships of production and trade that have contributed to the sector's creation and development and the economic and social conditions of the whole, particularly the relative pricing system that establishes the modalities of integration into the international markets (Cochet, 2012). This concept is used in the present research for several purposes, namely, in order to avoid selection bias and contamination. First, an analysis of the region's long-term agricultural development trends makes it possible to understand the context in which SOGUIPAH was set up in 1987: hence, the utility of this concept for matching at village level. The comparison village was actually chosen among 12 villages in the sub-prefecture of Péla, located directly North of the SOGUIPAH project zone. This subprefecture is the only one in the Kpèle region that has characteristics comparable with the SOGUIPAH project zone: agro-ecological conditions (climate, geomorphology and soil types), population (ethnic origin and density) and land use before the project. This was verified on the basis of a mapping exercise, aerial photos, field observations and interviews conducted throughout the Kpèle region.

Second, understanding agrarian system transformations over the long run makes it possible to identify and control for spill-over effects outside of the project intervention zone. These aspects will be illustrated in concrete detail below.

Third, a farming system analysis makes it possible to determine that relatively few farmers migrated outside the comparison zone (subprefecture of Péla, the village of Galaye), and that the SOGUIPAH zone had a regular inflow of migrants. It is thus possible to find in each zone farmers with characteristics that are comparable to those who migrated, as well as farmers who did not leave the zone at all.

The 'farming system' concept is relevant for making an intermediate-level analysis of the farm. The farming system is a model of the functioning and strategies of a subset of farms that have in common specific combinations of different crops in correlation with their production means (land, tools, knowledge, buildings, cash or access to credit), their available labour force and their personal strategies (Cochet, 2012). Although the objective differences between each farm appear to leave room for the researcher's subjectivity when building the farming system model, it is important to note that the rationale behind the farming system concept makes it possible to transcend the apparent arbitrariness. What underlies this methodological jump from a small number of interviews to a model is the belief that 'organizational laws ... govern reality and create types of structures in a limited number. The finite number of observed individuals 
makes it possible to understand these organizational laws and characterize these structures, and, as a result, give an overall vision of the organization of reality' (Couty and Winter, 1983, p. 30). In an agrarian context, there are a limited number of farming systems that give a sound representation of the logics and performances of most farms. Hence, identifying farming systems that existed at the 1987-1988 baseline allowed us to match the farm-cases of participants with the farm-cases of non-participants that initially belonged to the same farming systems.

To assess farming system performance, it is in most cases necessary to resort to a third concept: the 'cropping system' (and when relevant, to livestock systems). This concept applies not to a crop but to a plot of land (or a group of plots) cultivated in a particular way by the farmer. The 'system' refers to the crop or to the crops that are planted (and their possible mix), crop sequencing and the ensemble of techniques applied to them, in what order and under what soil and climate conditions (Cochet, 2012). The agronomic observations on each farm surveyed allow to identify and model each cropping systems found in the region.

It is at the levels of the cropping systems and farming systems that measuring the economic efficiency of production processes is relevant, whether this is calculated in terms of the labour power used (labour productivity), the land surface occupied (land productivity) or total income. ${ }^{2}$ This economic characterization of our different models (cropping systems and farming systems, with and without project) forms the basis for the quantification of the impacts. The economic analysis performed is a detailed financial evaluation at farm level as proposed by Gittinger (1972). It compares the net benefits of the project to the net benefits without the project. The impact of the project is in fact the sum of the net additional benefits, which is also equal to the sum of the additional income created year after year.

This implies that we should be able to obtain information on the economic results of each farming system for each of the past years. The recall method for interviewing farmers helped us to characterize the structural changes in the farming systems over each year considered: changes in surface areas dedicated to a cropping system, the modification of farming practices, the state of development of the plantations, investments in equipment, loans received or the adoption of technical innovations are all types of information that farmers can easily remember. The coherence of this information is validated by the researcher's analysis of labour availability or of the influence of contemporaneous events (changes in relative prices, the introduction of a new technique and so on). The performance of the various cropping systems complement the economic model: performance calculations are based on the study of current-day cropping systems, on direct observations and farmers' knowledge. The final income (in constant Guinean Francs - GNF) is calculated using combined information on the structural evolution of the farming systems, on cropping system performance and yearly constant prices for crops, inputs or land from 1988 to 2005.

The ex ante impact evaluation, required to quantify impacts during the lifetime of the project outputs, is based on assumptions formulated by the researcher. The main assumptions concern the trends in development observed nowadays (preferences for certain cropping systems, sustainability of the current farming practices or, on the contrary, the emergence of new trends) and which determine the structural evolution of farming systems proposed for the future. Assumptions on future prices were also formulated.

In concrete terms, the systemic approach consists of four steps: the agrarian system diagnosis; a large sample survey; farming system analysis; and finally economic modelling.

Step 1: The agrarian system analysis

A qualitative survey on the history of the agrarian setting and agro-ecological conditions was conducted with 41 key-informants in the SOGUIPAH intervention zone and in five villages 
outside of this zone. The survey focussed on the pre-project situation and agricultural development trends. SOGUIPAH's choice of intervention zone was strongly determined by the relatively flat landscape and richer alluvial soils of Diecke and Bignamou districts. These factors were necessarily taken into account for the choice of a counterfactual group, and interviews were complemented with direct observations and the study of topographical and pedological maps (SOCFINCO, 1988; SOCA II, 1990; BRGM, 2002) to find an appropriate comparison village. Triangulation was also possible by drawing on various documents, notably the 1983 census for population density, a report on coffee planters providing information on land occupation and economic data (BDPA-SCETAGRI, 1989a,b; SFC-SEDES-CEGOS, 1990) and a socio-economic baseline report on households of the SOGUIPAH zone (Merusi, 1989).

In the light of this, Galaye, located in Yomou county $40 \mathrm{~km}$ North-West of Kpoo, was chosen as the counterfactual village.

The agrarian system analysis is also the step that allows the identification of development trends and farming systems that existed before the project. Step 3 will present the three main types of farming systems that already existed in this area when the SOGUIPAH project was started.

The agrarian system analysis ultimately made it possible to identify the possible spillover effects induced by SOGUIPAH on the counterfactual village households. In fact, palm oil prices were affected and technological transfers took place.

Concerning palm oil prices, interviews with four local palm oil wholesale dealers (women) and price records ${ }^{3}$ evidence the influence of the SOGUIPAH project. Before the project, traders had been in fierce competition to obtain palm oil (called 'natural oil') from the villagers. Figure 1 shows a steady increase of palm oil prices between 1989 and 1995 (3 per cent per year). When SOGUIPAH oil (known as 'maquinot oil') flooded the market from 1995 on, the prices of the two oils became aligned and increased at a slower pace of no more than 0.9 per cent per. In the counterfactual scenario, we considered that the 'natural oil' would have continued to progress steadily (natural oil 'without' in Figure 1).

Moreover, technological transfers, namely, tenera oil palm plantations, began to spread outside the SOGUIPAH zone when farmers saw that tenera palm trees were much more

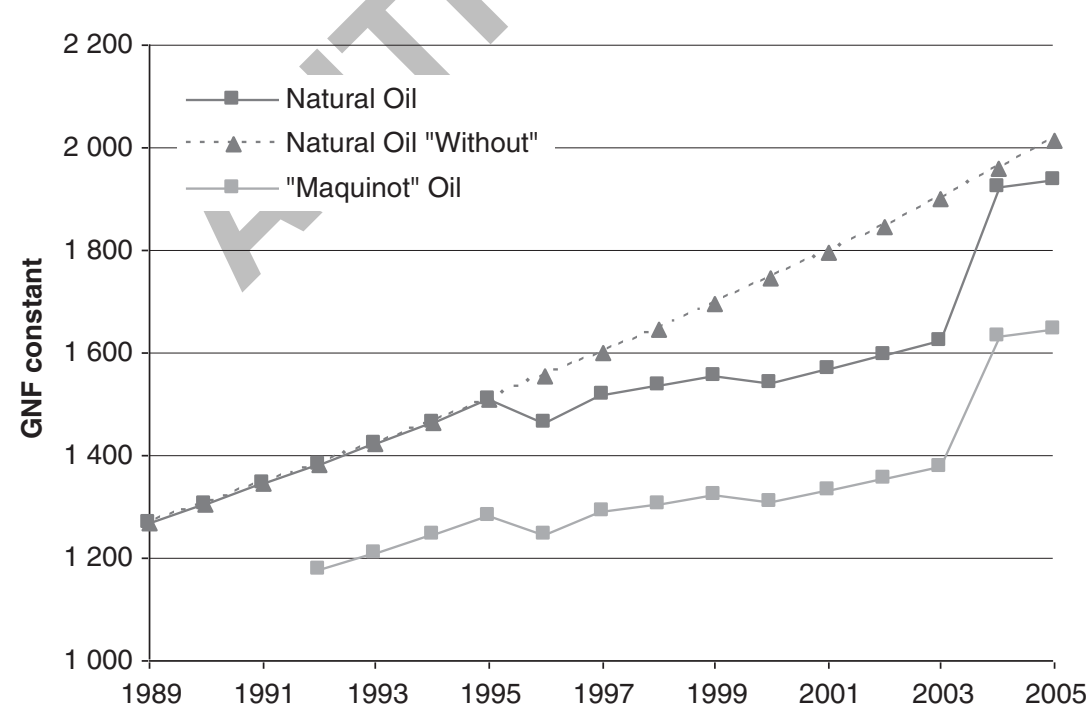

Figure 1: Palm oil prices between 1989 and 2005 (in constant GNF). 
productive. Other projects have introduced tenera palm trees and may also have had an influence, but our interviews confirmed that these projects gained the farmers' interest because of the example of SOGUIPAH. In our models of the counterfactual situation, we consider that farmers would not have planted tenera oil palms if the SOGUIPAH project had not been implemented.

To conclude, other projects were implemented across all of forested region of Guinea, the main ones being aimed at improving coffee plantations, lowland development and road improvements. These projects did not, however, intervene in SOGUIPAH's zone, although they would have done had the SOGUIPAH project not existed. Consequently, they do not invalidate the observations in Galaye, which remains a robust counterfactual situation.

\section{Step 2: A large sample survey}

Specialized rural interviewers speaking the Kpèle language were entrusted to carry out a large survey based on a structured questionnaire in the three villages. ${ }^{4}$ The questionnaire was aimed at collecting baseline data about the structural characteristics of the farms in 1987, about the trajectories followed by the households since that date and about the farms today. The questions on trajectories concerned structural evolutions, strategies and included, in Kpoo and Guilamou, and also involved discussions about the direct or indirect effects of SOGUIPAH on the farm. Two hundred and forty households were interviewed.

The questionnaire was designed beforehand by the principal researcher on the basis of information collected during the agrarian system analysis. The researcher was present during some of these interviews in order to explore in more detail the farming systems and the processes of change that were or were not attributable to the project.

Step 3: The farming system analysis

Thanks to the large sample survey, a broad picture of the farms in the three villages was available. In order to match the farms that were comparable before the project and to build the counterfactual scenario, a comparison based simply on the size, labour force and crops cultivated by the farms was not sufficient. A rigorous comparison required an understanding of the logic of the farming systems, elucidated during the agrarian system analysis. This analysis made it possible to identify groups of farms that belonged to the same farming systems before project start-up in the three villages. At this stage of the study, therefore, and taking the large survey as a basis, the researcher was able to constitute a purposeful sample of farms to be interviewed.

At this stage, in-depth interviews conducted by the authors collected quantitative and qualitative data about the farms in order to build the economic models for the various treatment and counterfactual groups. It was also during this step that the researchers were able to fine-tune their understanding of the existing farming systems and processes. In all, 73 in-depth interviews of the farms in Kpoo, Guilamou and Galaye were conducted. Information on the structural evolution of each farm and on the strategic choices made during the 1988-2005 period was collected using the recall method. The performances of the different cropping systems were also studied.

\section{Step 4: $\quad$ Modelling}

For a given farming system and for a given group (treatment or control group), the model was developed by the investigators, who chose the typical structural evolutions, strategies and economic performance experienced by the farms interviewed. The systemic coherence of these evolutions and performance was maintained for the specification of the model. This model has, 
above all, an economic goal in that it allows for a comparison of the economic results of the agricultural production process ${ }^{5}$ of different farming systems. Nevertheless, it is not based on the maximization of one indicator. Although we may assume that farmers aim to maximize their economic income (which includes monetary revenues and household consumption), a detailed understanding of their farming system enabled us to also integrate into our model the possibility that a farmer may prioritize improving food security or securing of his land, which does not always result in economic optimum.

Finally, in order to estimate the impact of the project over the lifetime of the plantations, it was important in this case to take into account the possible evolution of the farming systems with and without the project over the next 35 years.

This implied, of course, formulating many hypotheses, which were clearly stated in the model and can therefore be revised in the future. It was again thanks to the understanding of the systemic logics that it was possible to make a first set of hypotheses concerning the evolution of the structure of the farming systems. Second, price projections for local and export products were also formulated. The model for the future is therefore not linear but, on the contrary, includes forecasted variations.

To conclude this methodological presentation, we should underline that the systemic impact evaluation focuses on giving a faithful image of the diversity of impacts on different farming systems. The models are designed on the basis of an in-depth understanding of reality of the situation on the ground and not on a linear model. The counterfactual scenario was built using observations conducted on farms whose comparability to farms directly and indirectly concerned by the project was justified through a systemic approach.

The systemic impact evaluation of an agricultural development project must therefore be conducted in a small agricultural region, homogeneous in terms both of its agro-ecological characteristics and agrarian dynamics and of the farming systems that existed before the project. Measuring impact in this context necessarily requires constant back-and-forthing between a systemic analysis at different levels (what constitutes the agrarian system? what are the main farming systems? how have they evolved?) and evaluation (to what can we attribute this evolution?).

The use of this methodology for other types of projects would depend on being able to transcend the observations of a limited number of individuals by creating a sound model of typical cases whose systemic logics of functioning and evolving could be rigorously examined.

\section{Results}

\section{Baseline Situation}

The pre-project population density of Kpoo, Guilamou and Galaye were similar (less than 30 inhabitants per $\mathrm{km}^{2}$ in the rural areas of the counties according to the 1983 census). Rain-fed rice production was practised on the uplands with 7-10-year-long fallow. The lowlands had not yet been cultivated, other than occasionally, and were covered by raffia palms (Raphiavinifera) producing wine. During the slash-and-burn phase that precedes the seeding of rice on the uplands, the non-hybrid oil palms (Elaeisguineensis, var. dura) were always preserved, so much so that they gradually ended up creating genuine woodland above the plots left fallow. Before the setting up of SOGUIPAH, palm oil production was mainly carried out by young men just starting to establish their own farming activity; the absence of road networks limited commercialization beyond the village. 
Many farmers had established coffee plantations in the years leading up to and following independence (1958), due to the high market prices. In 1987, these former plantations constituted an authentic and diverse agro-forest on the outskirts of the villages and representing significant biomass. Kola trees, associated or not with coffee, were particularly abundant in this region. After the regime change and consequent economic liberalization in 1984, farmers resumed coffee production, creating new plantations, further away from their villages.

Three main farming systems can be identified for this period (1987) in all three villages.

The first type (Type 1) comprised large landowners: a homogeneous group possessing enough surface area and labour to cultivate 3-4 ha of rain-fed rice per year, with fallow periods of more than 10 years. The lowlands were used for producing raffia palm wine. The old plantations covered roughly 2 ha, with kola trees being more prevalent than coffee. The palm oil production of these farmers, especially the younger ones, was considerable. In 2005 GNF, their economic income was between GNF1 and 3.5 million (GNF600 000 per capita per year, equivalent to $€ 120$ per capita per year), most of which came from rice production and raffia wine.

The second category (Type 2) owned less land in 1987 than Type 1 farmers (for reasons relating to the local system of inheritance) and had less labour at their disposal. The farms of this group could only cultivate 1.5 ha of rain-fed rice yearly, with 7 years fallow. They did not possess coffee plantations, which generally stayed in the possession of the oldest child. They marginally exploited raffia palms for lack of sufficient manpower. Their rice production was complemented by commercialization of palm oil. Yearly agricultural revenues reached GNF800 000 (GNF250 000 per capita per year, equivalent to $€ 50$ per capita per year).

Finally, Type 3 was composed of small landholders who needed to borrow plots to cultivate rain-fed rice every year, maintaining fallow periods of less than 6 years. These farmers were not native to the region. An average surface area of 1.5 ha (or slightly more) had been planted with coffee and kola trees by their parents, to ensure definitive ownership. These producers already cultivated lowland rice, with fallow periods of 3-4 years. Raffia palms were thus rarely exploited. The agricultural revenues of these farmers were slightly higher than those of Type 2, thanks to the plantations: GNF1 100000 (GNF300 000 per capita per year, equivalent to $€ 60$ per capita per year).

\section{Comparison Groups' Trajectories}

The Galaye producers, starting from these three different situations, obviously evolved very differently during the period 1988-2005. First of all, the trajectories of the farming systems were influenced by considerable changes to population density due to both natural growth (2.7 per cent per year) and to an influx of 47000 refugees fleeing from wars in Liberia and Sierra Leone (Van Damme, 1999). The human impact on the zone was significantly accelerated. Moreover, during this period, rural roads were rehabilitated, which led to a greater market integration of the region.

As a result, rice fields expanded to village limits with a gradual densification of palm groves on sloping areas. Regrowth periods between cycles of slash-and-burn rice production shortened and rice yields began to fall. Consequently, rice was partly substituted by manioc, which continues to produce high yields even when fallow periods are short.

With these changes on uplands, the lowlands were increasingly used for rice production. Flooded rice production became more and more labour intensive, fallow periods were eliminated, and ploughing and transplanting techniques were adopted. Developing lowland areas had, up 


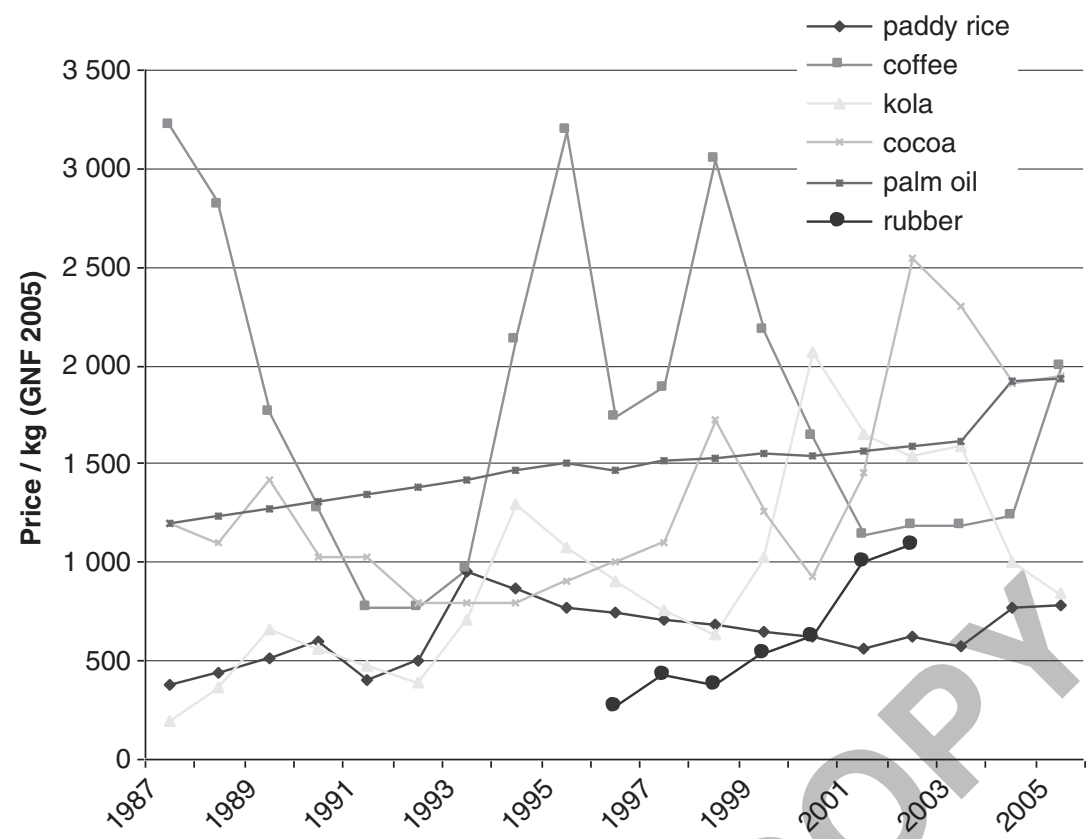

Figure 2: Evolution of relative prices for different products in the Forest Guinea region. Source: SOGUIPAH, Catholic Mission of N'Zérékoré (personal communication), USAID project Agency for Agricultural Commercialisation (ACA), IMF country reports for inflation rates.

until then, elicited little interest from producers. However, within the context of the changes described above, lowland improvement, which was proposed by several projects, dovetailed with the external agrarian dynamic, and many farmers thus began to take up this innovation.

The number of perennial coffee and kola plantations also increased, as farmers wanted to 'leave their mark' in terms of land ownership and lineage (so as not to find themselves dispossessed) and to 'prepare for the future'.

However, the plantation dynamics did not result in the total disappearance of rain-fed rice, far from it. One of the explanations may be found in the fluctuations of the prices of perennial crops (coffee, kola nuts), as compared with the price of rice, which remained stable throughout this period (Figure 2). Moreover, rice and manioc production represents food security for families and thus remains an important strategy.

All these evolutions were brought to light and better understood through the interviews conducted in the village of Galaye, and were taken into account in the models built for the counterfactual trajectories of farming systems.

In fact, the performances of the cropping systems show that in the counterfactual situation, plantations and rice production on sloping areas generated almost the same value added in 2005 . Only lowland area production (flooded or irrigated rice and raffia wine) and palm oil led to higher revenues (Figures 3 and 4). The latter is of course a priority for all families during the 4-month production period (and we will see that this is the same in the SOGUIPAH area). Raffia wine production remains limited to the families who have large lowland surface areas and sufficient daily time to spend on this activity. 


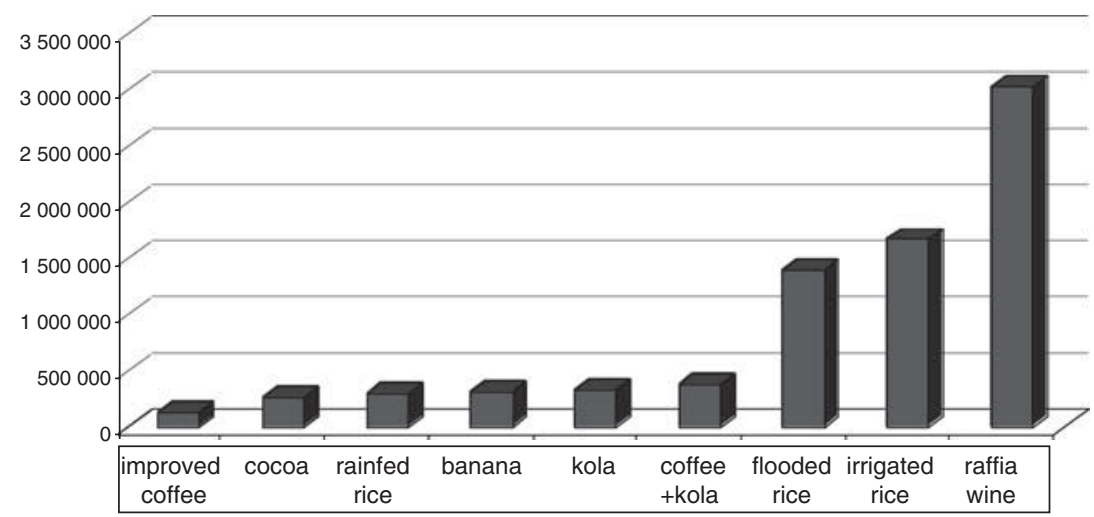

Figure 3: Value added per hectare of the different cropping systems. Source: Agrarian system analysis in Delarue (2007).

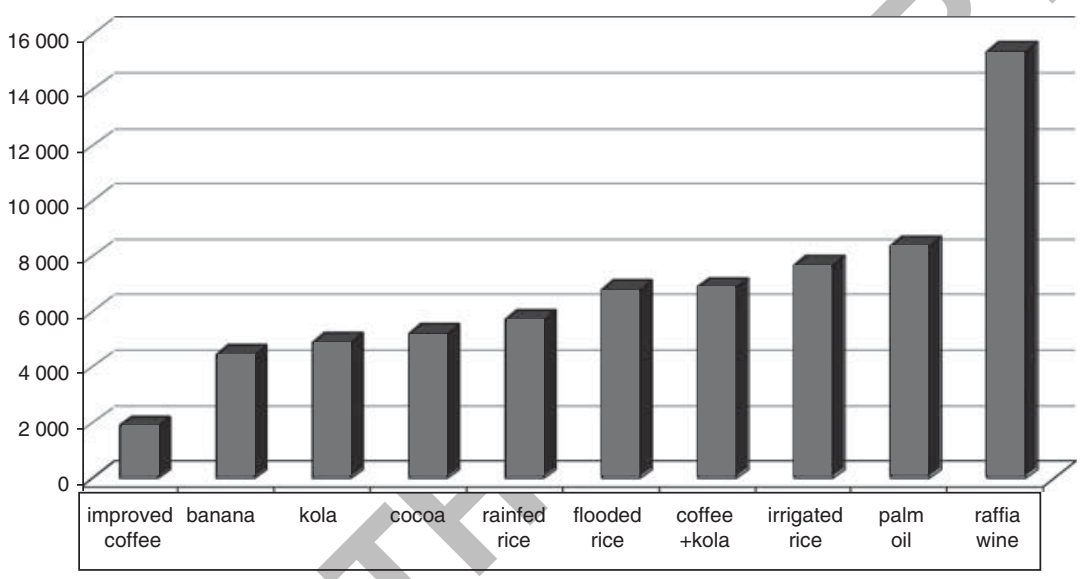

Figure 4: Value added per man-day of the different cropping systems. Source: Agrarian system analysis in Delarue (2007).

These findings already point to the main themes that are key to understanding the dynamics at work for the without-project group: land tenure issues, access to certain resources, the evolution of social lineage relationships, the relationship between price/competition and land/labour relationships.

Given these different aspects, it was possible to clearly define the trajectories of the three farming systems that existed before the project, which thus enabled a counterfactual to be reconstituted.

During this timeframe (1988-2005), Type 1 producers had both the land and labour resources to set up new plantations without compromising their rain-fed rice cropping systems. The benefits involved in appropriating the lowland areas led these producers to develop them both as a way to secure ownership and lighten their labour load (irrigated lowland areas require less weeding). The manpower available to these producers allowed them to exploit several raffia palms and produce sizeable volumes of palm oil as well (trajectory Galaye 1). 
Type 2 producers, who possessed limited sloping areas and had no plantations at the outset of the project, chose to plant and decreased the length of fallow for their rain-fed rice system. Those producers who had access to good-sized lowland areas developed part of this land, but because they prioritized rice production and lacked labour power they were unable to exploit raffia palms or produce high volumes of palm oil. The coffee and kola plantations that had started production in the early nineties provided these producers with supplemental income (trajectory Galaye 2).

The Type 3 producers also managed to develop their farming system despite having little leeway. They intensified flooded rice production and developed a small part of their lowlands with revenues collected from their plantations. They set up a new, smaller-sized coffee and kola plantations and eliminated the old plantations, thus freeing up space for rain-fed rice production. The producers with the most labour power also planted raffia palms in association with cacao, and produced significant amounts of homemade palm oil (trajectory Galaye 3).

In addition to these three primary trajectories, there were farmers who settled in the village in the 1990s and whose trajectories were also studied.

\section{Treatment Groups' Trajectories}

The farmers directly concerned by the project are (i) those who had contractual plantations, (ii) those whose lands were requisitioned for the creation of industrial plantations and (iii) those who were employees of SOGUIPAH. Farmers indirectly concerned are those who set up 'private' plantations (non-contractual) of palm and rubber trees or who were influenced by other indirect effects of SOGUIPAH (for instance, the emergence of a land market).

The impacts were highly differentiated, as we will show later. Only two typical cases will be presented here: (i) the impact on farmers originally belonging to the Type 1 farming system who obtained contractual plantations and (ii) the impact of an indirect effect of the SOGUIPAH project - the development of private plantations - by farmers belonging to Type 2 .

Although not a pre-condition imposed by SOGUIPAH, it was de facto necessary to have access to considerable manpower and even capital in order to be involved in the programme and obtain contractual plantation, because the producer himself had to prepare the plantation plot. This condition was fulfilled by farmers belonging to Type 1 . These farmers also owned large and conveniently located properties.

We give the example of Type 1 farmers in the village of Guilamou, where land was not requisitioned. This category of producers owned large, relatively isolated areas and cultivated $2-3$ ha of rain-fed rice yearly, respecting a 6-7-year fallow period. Undeveloped lowland areas were also cultivated by these farmers, who exploited five or six raffia palms yearly for family consumption and provisioning the self-help labour groups to which they belonged.

In 1992, these farmers abandoned their lowland (and consequently their raffia palms) to SOGUIPAH for development and received in return around 1 ha of improved lowlands, followed by rubber and palm oil planting material 2 years later. As a typical case, farmers received, under contract, 0.6 ha of palm trees the first year and 1 ha of rubber trees the following year. Considering the small size of their hybrid oil palm plots, most farmers decided to process as much as 90 per cent of the palm bunches and to sell oil themselves. This situation led to recurrent conflict with SOGUIPAH.

The economic benefits of the contractual plantations are very substantial and far above the other plantations that the farmers were exploiting, as illustrated in Table 1.

Yet, the consequences of exploiting oil palms and rubber on the other cropping systems implemented by the farmers must be also studied. There was a strong impact on labour allocation as the farmers themselves tap the rubber and process the oil. The amount of work needed for 
Table 1: Economic performance of SOGUIPAH contractual plantations compared to coffee associated with kola plantation (Type 1 farmer)

\begin{tabular}{|c|c|c|c|}
\hline For 1 ha (2005 prices in GNF) & Oil palm & Rubber & Coffee + kola \\
\hline Surface area of the plantation & $0.25-1$ ha & $0.25-1$ ha & - \\
\hline Investment workload (man-day/ha) & 200 & 290 & 136 \\
\hline $\begin{array}{l}\text { Investment monetary cost }=\text { contractual } \\
\text { labour-subsidies }\end{array}$ & $-120000(-€ 24)$ & $-390000(-€ 78)$ & 0 \\
\hline $\begin{array}{l}\text { Percentage of palm bunches not delivered } \\
\text { to SOGUIPAH }\end{array}$ & $50-90$ & - & - \\
\hline Equipement & Regular press & - & - \\
\hline $\begin{array}{l}\text { Workload on a typical year } \\
\text { (man-day/ha) }\end{array}$ & $224-300$ & 114 & 57 \\
\hline Value added/ha/year & $3300000(€ 660)$ & $2600000(€ 520)$ & $393000(€ 79)$ \\
\hline Value added/man-day & $13000(€ 2.6)$ & $23000(€ 4.6)$ & $6900(€ 1.4)$ \\
\hline
\end{tabular}

Source: Authors.

Table 2: Economic performance of 'private' oil palms and rubber plantations (Type 1 farmer)

\begin{tabular}{lcc}
\hline For 1 ha $(2005$ prices in GNF) & Second-generation oil palms & Seedling rubber trees \\
\hline Investment workload & 295 & 390 \\
Investment monetary cost & $-180000 / \mathrm{ha}^{\mathrm{a}}(-€ 36)$ & 165 000/ha $(€ 33)$ \\
Workload (man-day/ha) & 140 & 50 \\
Value added/ha/year & $1500000(€ 300)$ & $655000(€ 131)$ \\
Value added/man-day & $10700(€ 2.1)$ & $13100(€ 2.6)$ \\
\hline
\end{tabular}

${ }^{a}$ Investment cost is negative because the farmer produces rain-fed rice on the same area over the first year.

Source: Authors.

tapping not only forced the farmers to considerably reduce the time ( -30 per cent) they spent on cultivating rain-fed rice, but also prevented them from cultivating irrigated rice. As a result, they instead cultivated flooded rice in undeveloped lowland requiring a minimum time investment.

Although Type 1 farmers did not manage to obtain more support from SOGUIPAH, they decided to invest part of the revenues from their contractual plantations to 'privately' plant $1.5 \mathrm{ha}$ palm trees in 2001.

In fact, the most remarkable indirect effect of the SOGUIPAH project is the gradual development of private palm and rubber tree plantations - created spontaneously and independently of SOGUIPAH support - several years after implementation.

The dissemination of palm oil tree plantations 'outside' the project (far more frequently than rubber tree plantations) is particularly interesting. The farmers themselves would fetch palm tree seedlings from project plantations and set up their own nurseries before transplanting the trees. This initiative could be interpreted as a formidable endogenous development process, and a successful appropriation of new vegetal material - both results stemming at least partly from the SOGUIPAH project and thus considered as indirect effects.

Unfortunately, these indirect effects have not led to better revenues because the seedlings retrieved from the base of the hybrid tenera palms are second generation (F2); in terms of oil production, second-generation palms produce as little as 60 per cent of first-generation trees (Cochard et al, 2001). Similarly, the private rubber tree plantations are also established with seedlings germinated from rubber tree seeds. Their productive potential is only 25 per cent that of the clones (Penot, personal communication, 2006). Table 2 details the economic performances of these new cropping systems. 
The assumption for the future of the Type 1 farming system is the development of new private rubber plantations on 2 ha, in place of old coffee plantations situated near the village. The other land plots are in fact too 'landlocked' for new plantations. At cruising speed, oil palm will represent 20-30 per cent of the value added created by this farming system, and rubber will represent 30-40 per cent.

Despite the major differences between the trajectory of Type 1 farmers in Galaye (without project) and those in Guilamou (treatment: contractual plantations), the final economic impact proved to be minimal. The counterfactual situation is actually slightly more favourable: the total results for the effective project duration (48 years) of the group in Galaye are over GNF42 million, equivalent to $€ 8400$ (Figure 5). The contractual and private plantations made no difference, which proves that they are not sufficiently productive to increase incomes. In the treatment scenario, for the future, we consider that the plantations will not be renewed without SOGUIPAH's support. The limited results are due to the limited area of truly improved plantations generally allocated by SOGUIPAH to these farmers, and the fact that labour allocation resulted in the abandonment of other activities, such as raffia wine, natural oil, rainfed rice and irrigated rice production.

The producers from Kpoo and Guilamou that were in the Type 2 category before the SOGUIPAH project are among those who are today investing as fast as they can in private plantations, starting with second-generation palm trees (as these start producing quickly) and followed by rubber tree seedlings, when the distance from the plantation to a road is not too prohibitive.

Nonetheless, their limited labour force continues to be a handicap, especially as they usually hold a paid job tapping SOGUIPAH trees (paid income is included in the economic results below). Consequently, the new plantations established by the farmers themselves are rarely well-kept during the first few years, which leads to considerable pest damage (agoutis) and forces farmers to replant the same plot several times. Coffee and kola plantations are also usually left unweeded.

Over the first years, their income generally came from rain-fed rice production associated with their most recent coffee and kola plantations - just like in Galaye. Starting in 1999, their jobs as

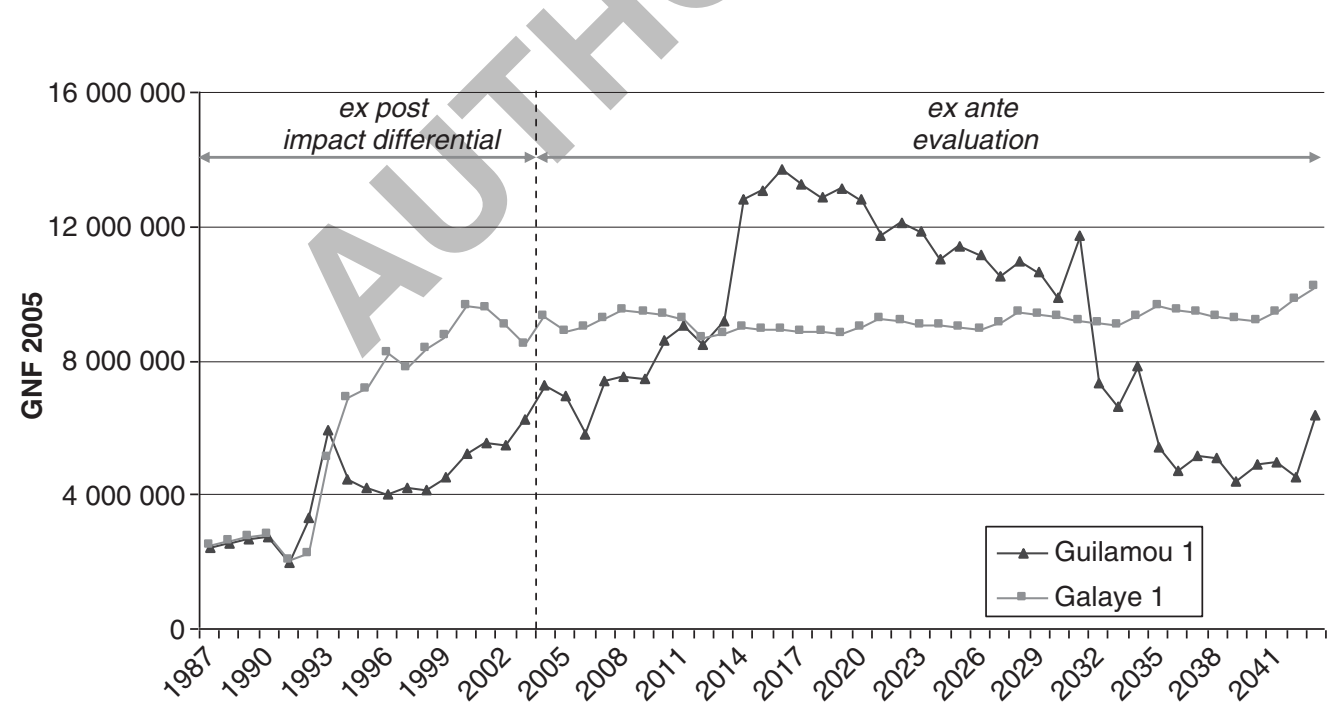

Figure 5: Comparison of net results: Type 1 farmers in Galaye (without project) and Guilamou (treatment: contractual plantations only).

Source: Surveys by the authors and F. Ravelomandeha. 


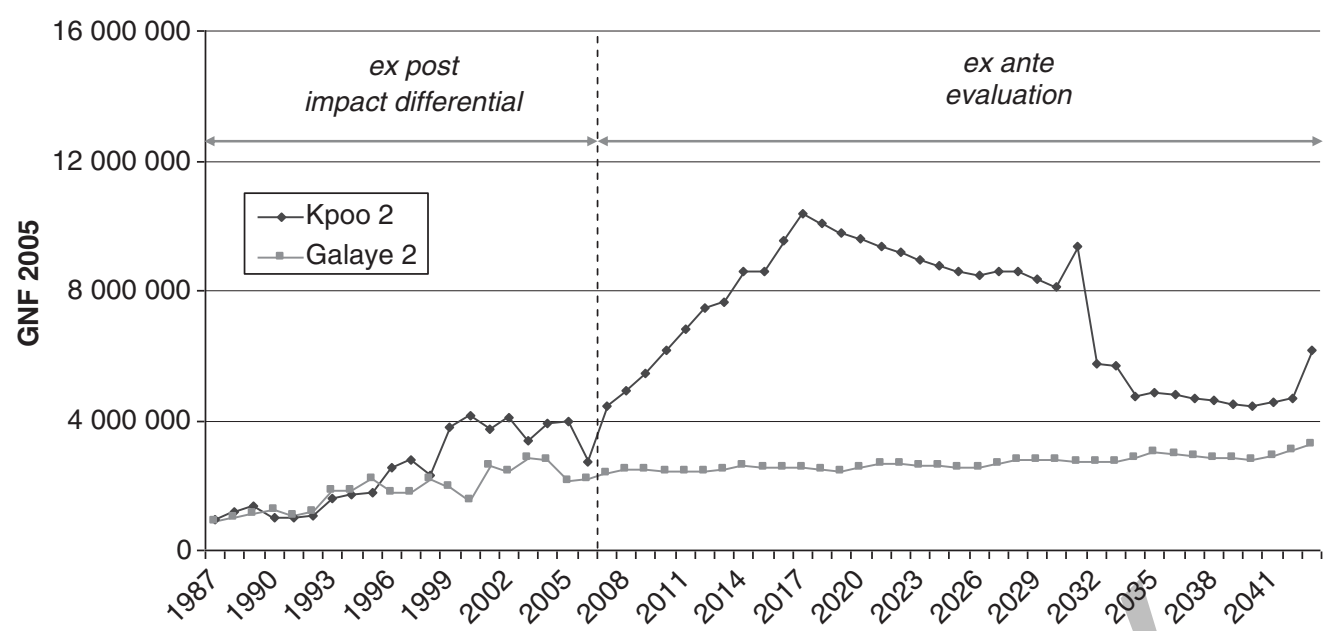

Figure 6: Comparison of net results: Type 2 farmers in Galaye (without project) and Kpoo (treatment: private plantations).

Source: Surveys by authors and F. Ravelomandeha.

tappers began to bring in revenues. They would rent developed lowland plots, cultivated for rice production and exploit a small number of raffia palms.

When the private plantations finally start to produce (2006 for the palm trees, 2014 for the rubber trees), these farmers will see a significant increase in their incomes. The expected results are higher than the 'without project' scenario, around GNF178 million, equivalent to $€ 35600$ in total. Thus, even in spite of the poor quality seedlings, it appears that private plantations are an advantageous option for these farmers, because without the project, their limited land area would not have generated much income (Figure 6).

In areas outside the SOGUIPAH intervention zone, the spontaneous dissemination of private palm plantations started a few years ago, whereas rubber tree plantations have only recently started to appear. As explained above, the impacts of these plantations (palm trees and rubber trees) are not included in the counterfactual scenario, as we were able to make sure that they would not have appeared in absence of the project. This phenomenon is both an original and imaginative component of the current development dynamic on perennial plantations mentioned above. It is a striking example of the spontaneous (and unforeseen) dissemination of new vegetal material (and often unknown techniques like tapping) that extends well beyond the initial boundaries of the project and among populations that were not part of the target group.

\section{Highly Differentiated Impacts}

The large-scale survey conducted by interviewers of 240 households enabled 11 trajectories related to the implementation of the project to be identified. Once each trajectory and impact was characterized and quantified through farming system analysis and modelling, this survey also made it possible to quantify a mean impact of the project, on the basis of the weight of each system and trajectory. The mean impact of the project in Guilamou was only €24 per year per household, due to its 'enclaved' location, whereas it was €200 per year in Kpoo.

Even so, a positive mean impact should not disregard the highly differentiated impacts that exist, depending on the original farming system and the various trajectories with and without the 
project. Former civil servants or traditional landlords benefitted from large contractual plantations, whereas other villagers were deprived of their land because of the needs of the project or received plantation areas that were too limited to improve their economic situation.

Therefore, it seems important that the impact evaluation of a complex development project include an analysis of the diversity of cases created by the intervention, directly or indirectly.

\section{Conclusion}

Identifying the direct and indirect effects of a project, describing the treatment and the counterfactual situations for different types of beneficiaries and quantifying the impact indicator chosen to represent observed differences are all important challenges for evaluating the impact of complex development projects.

By making a multi-level systemic approach the core point of a development project evaluation, the systemic impact evaluation method proposed here makes it possible to overcome a number of these challenges. Public interventions are always integrated into a larger dynamic that is only partially influenced, modified, slowed down or accelerated by these interventions. It is this dynamic that must thus be understood beforehand, in order to formulate the right questions for measuring impact. The accuracy of the conclusions will depend primarily on an understanding of the endogenous transformations, achieved thanks to careful contextual analysis, with the agrarian system analysis. The identification of a set of comparable units having evolved with and without the project depends on the understanding of what makes them fundamentally similar, hence the importance of relying once again on a systemic approach drawing on the farming system analysis.

This approach makes it possible not only to measure the real impact of a project using one or several evaluation criteria, but also proffers a great deal of reliable qualitative information likely to orient the project's decision makers and guide the elaboration of new interventions. In the case of the project set up by SOGUIPAH, the analysis reveals a highly differentiated impact on the different types of farmers. The project usually communicates about a theoretical mean income growth for a type of farmer that does not exist in reality: a family that had received 1 ha oil palms and 2 ha rubber trees for a contractual plantations should theoretically have multiplied its income by 10 . On the contrary, the use of a counterfactual reveals that the limited surface areas of contractual plantations distributed for families made no difference to a situation without the project where other opportunities arose. Finally, this impact evaluation teaches us that there was a true opportunity to improve the positive impacts of the project's indirect effects - the establishment of private palm oil and rubber plantations - by intervening at the level of the planting material chain.

\section{Notes}

1. These interviews were undertaken between November 2004 and October 2005.

2. Note that if a farming system is characterized by partial use of the family labour force in agricultural activities and systematic complementary income-generating activities, the latter are comprised in the economic model of the farming system. In this project, it was the case for farmers who were, for instance, also employed as contracted tappers.

3. Price records from SOGUIPAH and from the ACA, a programme financed by USAID.

4. Koop and Guillemot in the area covered by the project, and Gal aye for the counterfactual situation.

5. Non-agricultural activities like handicrafts and commerce are also taken into account in the model, but the agricultural production process forms a coherent whole. 


\section{References}

BDPA-SCETAGRI (1989a) Etude de faisabilité d'un projet riz de bas fonds dans la préfecture de Yomou. Paris, France: BDPA-SCETAGRI.

BDPA-SCETAGRI (1989b) Etude des possibilités de valorisation de la palmeraie naturelle en Guinée forestière. Conakry, Guinea: Ministère de l'Agriculture et des Ressources Animales.

BRGM (2002) Cartographie géologique de la Guinée forestière. 1:200 000. Conakry, Guinea : BRGM.

Cochard, B., Adon, B., Kouamé Kouamé, R., Durand-Gasselin, T. and Amblard, P. (2001) Intérêts des semences commerciales améliorées de palmier à huile (Elais guineensis Jacq.). In: International conference on the Future of Perennial Crops. Yamoussoukro; 5-9 November, Montpellier, France: CIRAD.

Cochet, H. (2012) The systeme agraire concept in francophone peasant studies. Geoforum 43(2012): $128-136$.

Cochet, H. and Devienne, S. (2006) Fonctionnement et performance économique des systèmes de production agricole: une démarche à l'échelle régionale. Cahiers Agricultures 15(6): 578-583.

Couty, P. and Winter, G. (1983) Qualitatif et quantitatif: deux méthodes d'investigation complémentaires. Paris, France: Ministère de la Coopération, Groupe AMIRA.

Delarue, J. (2007) Mise au point d'une méthode d'évaluation systémique d'impact des projets de développement agricole sur le revenu des producteurs, étude de cas en région Kpele (République de Guinée). $\mathrm{PhD}$ dissertation, AgroParisTech, Paris.

Gertler, P.J., Martinez, S., Premand, P., Rawlings, L. and Vermeersch, C.M.J. (2011) Impact Evaluation in Practice. Washington DC: The World Bank.

Gittinger, J.P. (1972) Economic Analysis of Agricultural Projects. Baltimore, MD and London: John Hopkins University Press.

Mazoyer, M. and Roudart, L. (2005) A History of World Agriculture: From the Neolithic Age to the Current Crisis. London: EARTHSCAN.

Merusi, L. (1989) Analyse socio-économique de la zone du projet agro-industriel de palmiers à huile et d'hévéas en Guinée forestière. Conakry, Guinea: SOGUIPAH.

SFC-SEDES-CEGOS (1990) Etude socio-économique des planteurs de café en Guinée forestière. Conakry, Guinea: MARA RC'2.

SOCA II (1990) Carte d'occupation des terres de la Guinée forestière. 1:100 000. Conakry, Guinea: MARA. SOCFINCO (1988) Carte pédologique zone C. Plan no. 23, SOGUIPAH. Paris: SOCFINCO France.

Van Damme, W. (1999) Les réfugiés du Libéria et de Sierra Léone en Guinée forestière. 1990-1996. In: Déplacés et réfugiés. La mobilité sous contrainte. IRD, Montpellier, France. 